\title{
Praktek Perdagangan Restriktif Dalam Pengalihan Teknologi Melalui Kontrak Lisensi
}

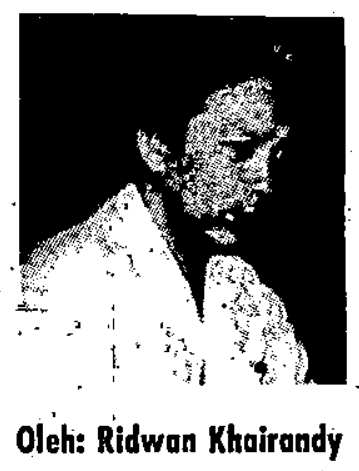

Minimal ada empat belas klausul Restrictive Business Practices (RBP) yang sering terdapat dalam berbagai kontrak alih teknologi melalui lisensi. Hal ini jelas sangat merugikan bagi negara-negara berkembang. Walaupun.PBB dalam resolusinya no. 25/65 tanggal 5 Desember 1960 telah memberikan himbauan untuk menghindari klausul semacam itu, namun banyak negara berkembang. berpendapat bahwa resolusi itu kurang diapresiasi oleh negara-negara maju: Maka menurut Ridwan Khairandy, Indonesia harus lebih mengoptimalkan pemberlakuan UU no. 6.1989 sebagai langkah antisipasi hukum nasional terhadap permasalahan di atas.

\section{Pendahuluan}

Setelah mengalami kebangkrutan ekonomi di zaman Orde Lama dan tidak terbayarnya hutang luar negeri yang sudah jatuh tempo, serta laju inflasi $20 \%$ - $30 \%$ per bulan ${ }^{\text {; }}$ pemerintahan Orde Baru mengadakan pendekatan baru dalam kebijaksanaan ekonominya, diantaranya adalah mengundang kembali masuknya modal asing ke Indonesia.

Bersamaan dengan itu, teknologi asing sepertinya 'membawa kita- kepada "Industrialisasi", dan dengan" amat bebas masuk melalui berbagai fasilitas penanaman modal asing dan berbagai perjanjian bisnis lainnya, seperti licence agreement; technical assistance agreement, turn key agreement, dan berbagai perjanjian bisnis yang sejenis. ${ }^{2}$ Semua teknologi dapat masuk dan tidak ada hambatan bagi masuknya teknologi asing tersebut ke Indonesia. ${ }^{3}$

Pengalihan teknologi seringkali sangat

1. Lihat Erman Rajagukguk, Indonesianisasi Saham, Bina Aksara, Jakarta, 1985, him 1.

2. Tödung Mulya Lubis, "Alih Teknologi: Antara Harapan dan Kenyataan", dalam Prisma, Edisi No. 4, Tahun XVI April 1987, him 5.

3. Id., him 8 . 
merugikan pihak penerima teknologi, karena dalam technology transfer agreement seringkali dimuat berbagai klausul Restrictive Bussiness Practices (RPB). Salah satu sifat klausul ini sangat membatasi akses ke pasar atau dengan sengaja membatasi persaingan.

\section{Teknologi}

Di dalam bidang ekonomi, teknologi biasa diartikan sebagai the application of scientific knowledge to the production of industrial goods and improvement of service. ${ }^{4}$ Dalam arti itulah B.N. Bhattasali mengatakan bahwa the term technology in the English language stands for the application of science to the industrial arts. ${ }^{5}$

Menurut rancangan Code of Conduct on the Transfer. of Technology yang dibuat United Nations Conference on Trade and Development (UNCTAD); teknologi itu meliputi setiap bukti adanya hak-hak industri baik secara tegas ataupun tidak seperti halnya lisensi; lisensi tentang produksi dan proses, informasi yang dipatenkan, hak-hak industri yang dilindungi terhadap pihak ketiga, buatan pabrik berdasarkan sanksi dan hal-hal lain yang dapat dijadikan obyek kontrak lisensi. ${ }^{6}$

Negara-negara yang tergabung dalam Organization on Ėconomic Cooperation and Development (OECD) membuat difinisi teknologi sebagai berikut :?

"Technology means systematic knowledge for the application of a process of for the renidering of a service, including any integrally associated managerial and marketing tecniques".

Keith Pavitt lebih memperjelas rumusan teknologi tersebut diatas : $:$

"Technology knowledge consist not only of acsess to scientific papers, formulae, blueprints, and hardware. It consist also and perhaps mainly of what people know and what people can do.

Pengertian teknologi yang lebih luas lagi dibuat oleh Worla Intelectual Property Rights (WIPO), yang oleh penulis dianggap sebagai definisi yang dapat menggambarkan dengan baik apa yang dinamakan dengan teknologi itu. Pengertian yang dibuat oleh WIPO tersebut adalah :9

"Technology. mean systematic knowledge for the manufacture of a product, the apllication of a process or the rendering a service, whether that knowledge reflected in an invention, an industrial design, a utility 'model or a new plant variety, 'or in tehnical information or skill, or in the services and the assistance of an industrial plant or the management of an industrial or commercial enterprise or its activities."

Dari beberapa definisi teknologi yang telah disebutkan di atas, ada beberapa segi atau aspek perlu diperhatikan yaitu :

1. Teknologi terdiri dari informasi yang mampu mengaplikasikan semua tahapan dari perencanaan, organisasi, dan operasi suatu industri atau perusahaan (komersial) dengan segenap aktivitasnya.

\footnotetext{
4. Sunaryati Hartono, "Pembahasan Kertas Kerja: Pemindahan Teknologi dan pengaturannya dalam Peraturan Perundang-undangan"; dalam Seminar Aspek-aspek Hukum Pengalihan Teknologi, Dipublikasikan oleh Badan Pembinaan Hukum Nasional -Binacipta, Bandung, 1981, him 189.

5. Ibid.

6. M. Daud Silalahi, "Rencana Undang-undang Alih Teknologit Pèrbandingan Perspektif", dalam Prisma, Edisi: April 1987, him 40.

7. OECD, North/South Technology, Paris, 1981.

8. Keith Pavitt, The Multinational Enterprise and the Transfer of Technology, George Allen \& Unwin Ltd., London, 1971, him 70.

9. WIPO, Licencing Guide for Developing Countries, Geneva, 1977, him 28.
} 
2. Teknologi mempunyai kontribusi untuk membuat setiap tahapan yang mencakup perencanaan, organisasi, dan operasi kegiatan suatu industri atau perusahaan; maka, teknologi tidak hanya terdiri dari scientific knowledge, tetapi juga pengetahuan bisnis atau organisasi.

3. Teknologi bisa berupa teknologi yang berwujud (bertubuh) dan tidak berwujud.

\section{Hak-Hak Hukum yang Berkaitan Dengan Teknologi}

Hak-hak hukum (legal rights) yang berkaitan dengan teknologi dapat dibagi dalam 2 (dua) bagian, yaitu : ${ }^{10}$

\section{Exclusive Industrial Property Rights}

Kategori pertama ini mencakup hak milik perindustrian yang memberikan hak eksklusif kepada pemiliknya dalam jangka waktu yang ditentukan. Termasuk dalam katagori ini adalah : (a) paten dan paten sederhana (b) desain produk industri (c) merek dagang dan merek jasa.

Ada beberapa karakteristik yang perlu diperhatikan sehubungan dengan hak-hak hukum yang berkaitan dengan teknologi dalam katagori yang pertama ini, yaitu :

1. Hak-hak tersebut akan diberikan bilamana telah memenuhi persyaratan dan kondisi tertentu yang ditentukan oleh undangundang (statutory rights);

2. Hak-hak tersebut dilindungi sebagai kekayaan (property); dan

3. Hak-hak itu berkaitan dengan persoalan teknologi yang sifatnya khusus. Kekhususan itu berasal dari persyaratan dan kondisi yang ditetapkan undangundang sebagai prasyarat bagi hak yang diberikan.

\section{Know how}

Know how dapat didefinisikan sebagai pengetahuan teknis atau organisasi yang memiliki kekhasan dalam bidang industri atau komersial, baik perseorangan maupun perusahaan, dan tidak merupakan milik umum (public domain). Know how merupakan akumulasi pengetahuan dan pengalaman ketrampilan praktis atau keahilian dan informasi untuk menjalankan manufaktur atau segala bentuk prosedur dan proses suatu produk."1

Wujud Know how dapat berupa infomasi atau data teknis dalam bentuk gambar, disket atau microfilm, misalnya rencana arsitektural bangunan pabrik, diagram perlengkapan pabrik, blue print mesin, daftar suku cadang, petunjuk-petunjuk operasi mesin atau untuk merakit komponen-komponen, daftar dan spesifikasi material, kalkulasi waktu bekerjanya mesin dan buruh, process flow chart, petunjuk pengemasan dan penyimpanan, laporan-laporan tentang aspek lingkungan dan stabilitas, dan job diskripsi personil; demikian juga pengetahuan teknis dan manajerial yang diperoleh dari pengalaman yang tersimpan dalam pikiran para ahli, yang dapat dikomunikasikan kepada yang lain melalui bantuan dan pelayanan teknis atau manejerial, misalnya demonstrasi/nasehat-nasehat tentang manufacturing operation, training, yang semuanya itu bertujuan untuk memecahkan suatu

10 Michael B, "Legal Arrangements for the Commercial Acquisition of Technology", Makalah Pada Seminar on Licencing and Technology Transfer Arrangement, yang di selenggarakan WIPO, Jakarta, 7-8 Maret 1990, hlm 5.

11 Nancy E. Muenchinger, "French Law on Property Transfers: An Overview", dalam Kojo Yelpaala et.al, (eds), Licencing Agreement : Patent, Know how, Trade Secrets and Software, Kluwer, Deventer, 1988. him 87-88. 
masalah di bidang industri, pertanian, dan perdagangan. ${ }^{12}$

\section{Alih Teknologi}

United Nations Centre on Transnational Corporation (UNCTC) mendefinisikan alih teknologi sebagai suatu proses penguasaan kemampuan teknologi dari luar negeri, yang dapat diurai dalam 3 (tiga) tahapan, yaitu :13

1. Peralihan teknologi yang ada ke dalam produksi barang dan jasa tertentu;

2. Asimilasi dan difusi teknologi itu ke dalam perekonomian negara penerima teknologi tersebut; dan

3. Pengembangan kemampuan indigeneous technology untuk inovasi.

Senada dengan itu, Bhattasali dalam bukunya Transfer of Technology among Developing Countries sebagaimana dikutip Sunarjati Hartono, menyatakan bahwa alih teknologi bukan hanya sekedar pemindahan, tetapi terutama alih teknologi yang tadinya asing, haruslah diadaptasikan ke dalam lingkungan yang baru, dan kemudian harus terjadi asimilasi serta inovasi sedemikian rupa, hingga teknologi asing itu akhirnya menjadi budaya bangsa yang menerima teknologi tersebuit. ${ }^{14}$

Proses alih teknologi yang demikian dapat dilihat dari tahapan pengembangan teknologi yang dicobakembangkan B.J. Habibie, yaitu :15

Tahap pertama dan yang paling mendasar adalah tahap penggunaan teknologi-teknologi yang sudah ada untuk proses nilai tambah dalam menghasilkan barang produksi yang memang sudah tersedia di pasaran.

Tahap yang kedua adalah tahap integrasi teknologi yang telah ada dalam desain dan produksi barang-barang yang baru sama sekali, artinya belum ada di pasaran.

Tahap ketiga adalah tahap pengembangan teknologi itu sendiri. Dalam tahap ini teknologi yang telah ada disempurnakan dan teknologi yang serba baru tersebut dikembangkan dalam upaya mendisain dan menghasilkan barang produksi untuk keperluan masa mendatang.

Tahap keempat dalam transformasi teknologi dan industri berwujud investasi baru dalam penelitian dasar.

Saluran Alih Teknologi Secara
Komersial
Pengalihan teknologi dapat dilakukan
baik melalui komersial maupun bukan
komersial. Pengalihan teknologi yang
dilakukan secara komersial dapat dilakukan
dalam berbagai bentuk. UNCTC dan
UNCTAD mencatat ada beberapa cara
pengalihan teknologi secara komersial, yaitu
:16 (1) Foreign Direct Investment (2) Joint
Venture (3) Licence (4) Franchising (5)
Management Contract (6) Marketing Contract
(7) Technical Service Contract (8) Turn Key

12. J.B. Lumenta, "Beberapa Aspek Hukum Lisensi Paten dalam Praktek", Pusat Kajian Hak Milik Intelektual Fak Hukum Universitas Tarumanegara, yang diselenggarakan di Jakarta tanggal 13 Mei - 19 Juni 1991, him2.

13. United Nations Centre on Transnational Corporations, Transnational Corporation and Technology Transfer: Effects and Policy Issues, United Nations, New York, 1982, him 1.

14. Sunarjati Hartono, op. cit., him 190.

15. B.J. Habibie, limu Pengetahuan, Teknologi, dan Pembangunan Bangsa (Himpunan Pidato 1994). Badan Pengkajian Penerapan Teknologi (BPPT). Jakarta, 1985, him 26-27, dan 43.

16. Lihat Rancangan Intemational Code of Conduct on Transfer of Technology, UNCTAD, 1989. Lihat juga UNCTC, op. cit., him 2. 
Contract dan (9) International sub-contracting.

\section{Technology Contract}

Alih teknologi yang dilakukan secara komersial berkaitan dengan apa yang dinamakan dengan contract for the transfer of technology atau technology contract. Istilah tersebut banyak digunakan dalam beberapa ketentuan hukum nasional. Tetapi, hingga sekarang ini belum ada satu bentuk atau tipe kontrak yang secara khusus dapat diidentifikasikan sebagai suatu kontrak alih teknologi baik untuk level peraturan hukum nasional, regional, maupun internasional. $\mathrm{Di}$ dalam praktek pada kontrak-kontrak tersebut dijumpai sejumlah perbedaan titel (tite/s). ${ }^{17}$

OECD mengklasifikasikan kontrakkontrak teknologi itu ke dalam 2 kategori yaitu: Pertama, pengalihan (transfer) yang berjangka pendek (one-off operation) antara lain meliputi turn key factories, paten, personal training. Kedua, kontrak-kontrak yang menimbulkan keterkaitan permanen (permanent link) seperti continuing technical asassistance dan contract for the maintenannce of instalations. ${ }^{18}$

UNCTC membagi kontrak-kontrak teknologi tersebut ke dalam 2 kategori utama, yaitu: Pertama, Licencing Agreements (kontrak semacam ini antara lain mencakup kontrak yang berkaitan dengan paten, Know how, merek perdagangan, dan franchise). Kedua, kontrak-kontrak yang berkaitan dengan bantuan teknik (technical assistance), yang termasuk dalam kategori kedua ini antara lain : turn key contract, contracts for providing technical services, dan design and engineering contracts. ${ }^{19}$

Perbedaan ini didasarkan pada tujuan kontrak, kewajiban para pihak, hubungan kontraktual, dan cara-cara pembayaran teknologi yang dialihkan. Perbedaan utama kedua kategori tersebut terletak pada fakta, bahwa kontrak lisensi adalah suatu hak yang dilindungi, sedangkan kontrak-kontrak yang berkaitan dengan bantuan teknik mempunyai karakteristik perjanjian jual beli. ${ }^{20}$

Dari sejumiah kontrak teknologi atau cara-cara pengalihan teknologi yang disebut di atas, kontrak lisensi merupakan cara yang terpenting dan terefektif. ${ }^{21}$

\section{Kontrak Lisensi dalam Alih Teknologi}

Dengan kontrak lisensi secara tipikal licencor memberikan hak kepada licencee untuk memakai hak milik intelektualnya dilindungi paten, dengan imbalan berupa royalty dari pihak licencee yang ingin memperoleh manfaat dari teknologi yang dimiliki licencor sebagai pemegang paten; dan bersamaan dengan itu sekaligus - melindungi lecencee terhadap pihak ketiga atau saingannya.

Di dalam konteks alih teknologi, seringkali terjadi salah tafsir, seolah-olah dengan kontrak lisensi paten atau bahkan dalam transaksi jual beli mesin dan/atau peralatan suatu industrial plant sudah

17. D. Kokkini-latridou, "Contracts for the transfer of Technology", dalam C.C.A. Voskuil - Z. Parac - J.A. Wade (eds) Hague-Zagreb Essay 6 on the Law on International Trade: Crediet and Guarantee Financing

Transfer of Technology, Martinus Nijhoff Publisher, Dordrecht, 1987, hlm 267.

18. Ibid.

19. Ibid.

20. Ibid.

21. Lihat Amir Pamuntjak, "Pengaturan Penyelenggaraan Pengalihan Teknologi (suatu Analisa tentang Tatakerja Pengalihan Teknologi di luar dan dalam negeri", makalah pada Seminar Aspek-aspek Hukum Pengalihan Teknologi, yang dipublikasikan oleh BPHN - Binacipta, Bandung, 1981, him 220. 
dianggap transaksi alih teknologi. Memang, tidak dapat dipungkiri, mungkin saja alih teknologi terjadi melaluik kontrak lisensi paten, perjanjian keagenan, perjanjian jual beli, atau perjanjian kerjasama patungan dalam penanaman modal asing, asalkan di dalamnya diatur ketentuan tentang Know how untuk mengkomunikasikan pengetahuan dan informasi teknis dan/atau bantuan serta pelayanan teknis lainnya. ${ }^{22}$

Jadi, adanya'kontrak lisensi paten, tanpa disertai kontrak lisensi Know how dapat dipastikan akan mengalami banyak hambatan dan hampir tidak mung'kin mendapalkan akses penguasaan teknologi yang dipatenkan tersebut, karena tidak semua pengetahuan (dalam hal ini Know how) yang diperlukan untuk melaksanakan penemuan itu diuraikan dalam deskripsi pada dokumen paten yang bersangkutan.

Oleh karena itu, di dalam praktek transaksi yang berkenaan kontrak teknologi ini melibatkan beberapa kontrak. Yang pertama adalah kontrak lisensi paten (bilamana teknologi atau penemuan tersebut dipatenkan), kemudian diikuti oleh beberapa kontrak terkait dengannya seperti Know How, Licence agreement, Technical Assistance Agreement, atau Service Assistance Agreement. Namun terkadang diadakan kontrak gabungan seperti Licence and Technical Assistance Agreement.

Dari sudut pandang licencee, pengalihan teknologi melalui kontrak-kontrak lisensi dianggap menguntungkan, karena kontrak lisensi dapat merupakan :

1. Akses perolehan atau penguasaan teknologi secara cepat;

2. Penghematan waktu serta usaha dalam riset dan pengembagan;

3. Penambahan sumber daya pengetahuan. Kemudian licencor sendiri, pengalihan teknologi melalui lisensi juga dianggap sangat menguntungkan, karena licencor akan :23

1. Mendapatkan royalti dari sejumlah hasil penjualan tanpa harus turut serta dalam investasi dalam rangka membuka pasaran ekspor;

2. Pengembangan pasar luar negeri;

3. Penciptaan pasar luar negeri bagi bahan baku yang bertalian dengan peralatan atau jasa;

4. Menghasilkan arus dana finansial untuk melanjutkan riset dan pengembangan di daerah yang sama atau daerah lain, dan

5. Menghindari beaya-beaya yang melatarbelakangi mengapa licencor mau mengalihkan teknologi melalui lisensi tersebut, motifnya adalah profit.

\section{Kontrak Lisensi Teknologi di Indonesia}

Tidak diketahui secara pasti berapa banyak dan berapa ragam teknologi yang masuk ke Indonesia. Namun diketahui secara pasti arus alih teknologi itu sangat besar dan tampaknya akan terus mengalir tanpa henti. ${ }^{24}$

Di dalam praktek, arus alih teknologi berjalan sangat bebas. Dari segi hukum sendiri, tidak ada hambatan bagi masuknya teknologi asing ke Indonesia. Semua kontrak yang berkaitan dengan pengalihan teknologi dilindungi oleh asas kebebasan berkontrak sebagaimana diatur pasal 1338 Kitab Undang-Undang Hukum Perdata Indonesia. Selain itu Hukum Kontrak Indonesia menganut sistem "terbuka" yang berarti

22. J.B. Lumenta, op. cit., hlm 1-2.

23. Roger D Taylor, "Technology Transfer and Investment - The Transferror's Perspective," Makalah pada National Seminar on Licencing and Technology Transfer Arrangement, yang diselenggarakan oleh WIPO, di Jakarta, tanggal 7-8 Maret 1990.

24. Todung Mulya Lubis, op. cit., him 5. 
setiap orang bebas untuk membuat segala macam kontrak. Sebagai konsekwensi dianutnya sistem "terbuka", maka ketentuan-ketentuan yang terdapat dalam Buku III KUHPerdata itu mempunyai sifat optional law (aanvullensrecht), berarti para pihak yang mengadakan perjanjian mempunyai kebebasan menentukan ketentuanketentuan dan syarat-syarat yang dikehendaki para pihak sendiri.

Kontrak alih teknologi merupakan urusan swasta murni tanpa campur tangan pemerintah. Tidak ada kewajiban para pihak untuk melapor atau mengumumkan isi kontrak lisensi kepada pemerintah.

Akibat kurangnya informasi, karena tidak adanya kewajiban untuk melaporkan kepada pemerintah apalagi kepada.umum, ditambah lagi dengan minimnya pengetahuan kita mengenai kontrak-kontrak internasional yang berkaitan dengan alih teknologi, maka bisa saja dalam praktek kontrak-kontrak ini mengatur teknologi yang sudah usang (obsolute) dan hanya berurusan dengan industri substitusi impor yang sudah kita kuasai. Jadi disini tidak ada teknologi baru yang masuk. Oleh karenanya dalam hal ini tidak terjadi alih teknologi. ${ }^{25}$

Untuk mendukung motif profit pemilik teknologi atau licencor dalam kontrak lisensi, dan untuk menghindari kemungkinan timbulnya kerugian bagi pemilik teknologi, maka dalam berbagai kontrak lisensi, pemilik teknologi berusaha untuk mengamankan kepentingannya itu. Hal itu dilakukan dengan menambahkan ketentuan-ketentuan yang membatasi gerak penerima teknologi. Pembatasan-pembatasan yang ada dalam kontrak lisensi tersebut dinamakan restrictive business practices (RBP).

\section{Perdagangan Restriktif}

Menurut United Nations Confrence on Rectrictive Business Practices, Multilarelly Agreed Equitable Principles for the Control of RBP, TOT/RBP/CONF/10 of May 2, 1980 , Praktek Bisnis Restriktif merupakan tindakan atau perilaku perusahaan yang melalui penyalahgunaan atau pengambilalihan posisi dominan kekuatan pasar, membatasi akses ke pasar atau dengan sengaja membatasi persaingan, sehingga berdampak negatif pada perdagangan internasional, khususnya pada perdagangan dan pembangunan ekonomi negara-negara berkembang melalui perjanjian tertulis atau tidak tertulis diantara mereka; yang berdampak negatif sama.

Klausul-Klausul RBP yang sering terdapat di dalam berbagai kontrak alih teknologi melalui lisensi sekarang ini, diantaranya adalah :

\section{Exclusive Grant Back Provisions}

Klausul ini mensyaratkan penerima teknologi untuk memberikan hasil inovasi yang dilakukan atas teknologi tersebut kepada pemilik secara cuma-cuma;

2. Challennges to Validity

Klausul ini melarang menerima teknologi untuk mempersoalkan apakah paten atau hak-hak perlindungan lainnya terhadap penemuan yang berkaitan dengan alih teknologi masih berlaku atau tidak;

\section{Exlusive Dealing}

Klausul ini melarang penerima teknologi mengadakan perjanjian sejenis pihak lain;

\section{Restriction on Research}

Pembatasan untuk mengadakan riset yang ditujukan untuk menyerap atau mengadakan modifikasi terhadap teknologi yagn dialihkan;

\section{Restriction on Use of Personnal} Dengan klausul pembatasan penggunaan tenaga kerja ini penerima teknologi diharuskan memakai tenaga kerja yang

25. Id., hlm 9 . 
ditentukan oleh pemilik teknologi;

\section{Price Fixing}

Klausul ini mengatur ketentuan harga produksi oleh pemilik teknologi;

\section{Restriction on Adaption}

Klausul memuat pembatasan terhadap modifikasi teknologi pada penerima. Klausul ini melarang penerima untuk memodifikasi atau mengadaptasi teknologi yang bersangkutan dengan kebutuhan yang nyata di lingkungan pihak penerima teknologi.

8. Exclusive Sales or Respresentation Agreement

Klausul ini memuat perjanjian perjanjian penjualan atau agen tunggal dengan pemilik teknologi;

9. Tying Arrangement

Klausul ini ketentuan-ketentuan yang mengikat penerima teknologi, misalnya keharusan menerima inovasi teknologi tersebut untuk penemuan baru dari pemilik teknologi di kemudian hari, dan keharusan pembelian bahan baku;

10. Export Restriction

Klausul ini memuat larangan pada penerima teknologi untuk mengekspor produksi yang dihasilkan dari teknologi yang dialihkan;

11. Payment and other obligations after Expiration of Industrial Property Right Klausul ini mengatur pembayaran royalty atau kewajiban-kewajiban lain dari penerima teknologi setelah habisnya waktu perlindungan hak milik perindustrian;

12. Restriction after Expiration of Arrangement

Klausul ini memuat pembatasan setelah berakhirnya jangka waktu kontrak. Disini dimuat larangan untuk menggunakan teknologi setelah berakhirnya jangka waktu kontrak, kecuali bilamana teknologi tersebut masih dilindungi oleh hukum atau belum menjadi hak hukum (public domain);

13.Pembatasan volume, ruang lingkup maupun kapasitas produksi;

14.Syarat memberikan saham pada pemilik teknologi atau partisipasi pemilik teknologi dalam manajemen perusahaan;

Tidak semua klausul RBP tersebut di atas muncul dalam kontrak-kontrak pengalihan teknologi pada umumnya. Akan tetapi bagi setiap kontrak khusus selalu diajukan beberapa macam dari klausul RBP di atas.

Adanya klausul RBP dalam kontrak lisensi yang demikian itu jelas sangat merugikan, tidak hanya bagi penerima teknologi, tetapi kepentingan-kepentingan negara berkembang, sehingga meniadakan manfaat-manfaat yang semula diharapkan dapat diperoleh melalui pemakaian teknologi tersebut. ${ }^{26}$

\section{Code of Conduct on Transfer of Tecnology}

Sebagai tindak tanjut pembentukan Tata Ekonomi Internasional Baru ${ }^{27}$, Section IV Resolusi Majelis Umum Nomor 3202 (XXIX) Menegaskan :

1. to formulate on International code of conduct on transfer of technology.

2. to give acces on improved term to modern technology and to adapt that technology, as appropriate, to spesific economic, social and acological conditions and carrying stages of development in

26. J.B. Lementa, "Pengaturan Masalah Alih Teknologi Suatu Tinjauan Komperatif", Makalah, Amroos Law Consultant, Jakarta, 1991, him 1.

27. Perhatikan Resolusi Majelis Umum PBB Nomor 3201 (XXIX) dan Resolusi Majelis Umum PBB Nomor 3202 $(X X I X)$. 
developing countries.

Setelah itu berdasarkan Resolusi Majelis Umum PBB Nomor 3362 (S-VII) tanggal 16 September 1975, penyusunan Code of Conduct on Transfer of Tecnology (selanjutnya disebut TOT Code) diteruskan melalui UNCTAD.

Berdasarkan Resolusi Majelis Umum PBB Nomor 32/188, Desember 1977. Konfrensi PBB tentang TOT Code yang diusulkan berhasil dilaksanakan pada tanggal 10 Oktober 1978 selama 4 minggu. Dalam konfrensi ini berhasil disajikan naskah TOT Code baik dari kelompok 77 sebagai basic draft, dari kelompok negara-negara maju sebagai response draft that countere the proposal of the group of 77 , maupun dari kelompok negara-negara sosialis yang pengajuannya dilakukan secara bertahap.

Dalam konfrensi ini terjadi pertentangan mengenai Praktek Perdagangan Restriktif (Restrictive Business Practice), tanggung jawab, dan kewajiban para pihak, masalah hukum yang dipergunakan (aplicable law) serta penyelesaian sengketa (settlement disputes).

Berkaitan dengan persoalan praktek perdagangan resteriktif dalam pengendalian teknologi, pasal 4 Rancangan TOT Code menyebutkan 14 klausul yang harus dihidnari dan dilarang dimuat dalam transaksi alih teknologi, yaitu : exclusive grant back provision, Challenges to valitidity, Exlusive dealing, restrictions on research, Restrictions on use of personnel, Price fixing, Restrictions on adaptation, Exclusive Sales or representation agreements, Tying Agreements, Exprot restriction, Patent pool or cross licencing agreements and other arrangements, Restriction on publicity, Pay- ment and other obligations after expiration of industrial property rights, dan Restriction after of arrangement.

\section{Set of Multilaterally Agreed Equi- table and Rules for The Control of Restrictive Business Practices}

Berkaitan dengan Praktek Perdagangan Restriktif ini, PBB juga berusaha mengatasinya dengan jalan menyelenggarakan United Nations Confrence on Restrictive Business Practise. Dalam sidangnya yang kedua pada tanggal 22 April 1980, berhasil disetujui suatu dokumen penting yang disebut Set of Multilaterally Agreed Equitable Priciples and Rules for the Control of Restrictive Business Practices. ${ }^{28}$ Hasil Konprensi ini kemudian dimuat dalam Resolusi Majelis umum PBB Nomor 35/65 tanggal 5 Desember 1980.

Dengan memperhatikan kepentingan semua negara khususnya, kepentingan negara berkembang, perangkat hukum ini dirumuskan untuk mencapai tujuan-tujuan sebagai berikut ${ }^{29}$

1. Menjamin agar praktek-praktek bisnis yang merugikan tidak menggerogoti manfaat yang timbul dari penghapusan tarif dan non tarif yang mempengaruhi perdagangan dunia, khususnya perdagangan dan pembangunan negara-negara berkembang;

2. Mengusahakan tercapainya efisiensi dalam perdagangan internasional dan pembangunan, khususnya bagi negaranegara berkembang, sesuai dengan tujuan atau cita-cita nasionalnya di bidang ekonomi, pembangunan sosial serta struktur ekonomi yang ada, seperti melalui: Penciptaan, penggalakan dan perlindungan terhadap persaingan

28. Tinjauan Praktek Bisnis Restriktif, Departemen Perdagangan (untuk kalangan sendiri), 1992, hlm 3. 29. Id., hal 11-12. 
(menumbuhkan dan menjaga persaingan yang sehat); pengawasan terhadap konsentrasi modal dan atau konsentrasi kekuatan ekonomi, dan mendorong penemuan-penemuan baru;

3. Melindungi dan meningkatkan kesejahteraan sosial pada umumnya, serta melidungi kepentingan konsumen baik di negara maju maupun di negara berkembang pada khususnya;

4. Menghapuskan kerugian dalam perdagangan dan pembangunan sebagai akibat praktek-praktek bisnis yang merugikan yang dilakukan perusahaan transnasional, sehingga dapat membantu memaksimalkan manfaat perdagangan internasional, khususnya bagi perdagangan dan pembangunan negara berkembang, dan

5. Menyediakan suatu perangkat multilateral tentang prinsip dan aturan bagi pengawasan terhadap praktek-praktek bisnis yang merugikan, di tingkat internasional, sehingga dapat membantu atau memperkuat penerapan aturan kebijaksanaan yang sama pada tingkat nasional dan regional:

Pérangkat hukum tersebut memuat prinsip-prinsip dan aturan-aturan yang berlaku dalam semua transaksi barang dan jasa, baik yang dilakukan perusahaan nasional maupun perusahaan transnasional. Perangkat hukum ini juga memuat prinsipprinsip dan aturan-aturan yang sebaiknya dipakai pemerintah dalam tindakan yang diambilnya di tingkat nasional, regional maupun internasional dalam rangka pengendalian praktek bisnis restriktif tersebut.
Namun demikian, setelah sekian lama disepakati, muncul berbagai komentar mengenai efektivitas pelaksanaan ketentuan tersebut. Negara-negara maju umumnya merasa, bahwa prinsip dan aturan yang tercantum dalam perangkat tersebut telah dilakșanakan secara memuaskan. Sementara itu negara-negara maju dalam menahan perusahaan-perusahaan melakukan praktek yang merugikan perdagangan dan perekonomian negaranegara berkembang. ${ }^{30}$

\section{Antisipasi Hukum Nasional}

Secara umum, sebenarnya Pemerintahan Indonesia sudah mencoba mengantisipasi praktek perdagangan restriktif tersebut. Antisipasi hukum tersebut telah dituangkan dalam UU Paten dan Merek.

Menurut UU No. 6 tahun 1989, perjanjian lisensi (paten) dilarang memuat ketentuanketentuan yang langsung maupun tidak langsung dapat menimbulkan kerugian perekonomian industri Indonesia atau membuat pembatasan yang menghambat kemampuan bangsa Indonesia dalam menguasai dan mengembangkan teknologi pada umumnya dan yang berkaitan dengan penemuan yang diberi paten pada khususnya. ${ }^{31}$ Selain itu UU No. 6 tahun 1989 juga telah mewajibkan setiap perjanjian lisensi paten didaftarkan pada kantor paten dan dicatat dalam Daftar Umum Paten. ${ }^{32}$ Hanya saja, hingga hari ini peraturan pelaksanaan ketentuan ini belum ada. Ketentuan yang senada juga dianut UU No. 19 Tahun 1992 tentang Merek. ${ }^{33}$

Sehubungan dengan ini patut pula diperhatikan ketentuan Trade Related Intectual Property Rights (TRIPs), khususnya

30. Id., him 3.

31. Pasal 78 ayat (1)

32. Pasal 79.

33. Perhatikan pasal 48 ayat (1) UU No. 19 Tahun 1992. 
pada bagian 8 mengenai Pengendalian Praktek-Praktek Persaingan Curang dalam Perjanjian Lisensi (Control of Anti-Competitive Practices in Contractual Licences). Pasal 40 Trips itu menyebutkan, bahwa (negara) anggota sepakat bahwa beberapa praktek perlisensian atau persyaratan-persyaratan yang berkaitan dengan hak atas kekayaan intelektual (HAKI) yang menghambat persaingan dapat berakibat tidak baik bagi perdagangan dan dapat menghambat proses alih dan penyebaran teknologi. Oleh karena itu, tidak satu ketentuanpun di dalam persetujuan TRIPs ini yang menghalangi (negara) anggota untuk menetapkan dalam peraturan perundang-undangan nasionalnya praktek-praktek perselisihan atau persyaratan-persyaratan yang dalam hal tertentu merupakan penyalahgunaan HAKI yang berakibat tidak baik terhadap persaingan dalam pasar terkait.

Ketentuan-ketentuan lisensi paten atau merek saja, sekarang bagaimana dengan pengaturan lisesnsi lainnya? Apakah sekarang Indonesia perlu menyusun pengaturan khusus UU tentang Alih Teknologi?

Pemerintah Indonesia melalui Badan Pembinaan Hukum Nasional pada tahun 1980 - 1982 sebenarnya sudah berhasil menyusun Naskah Akademis Rancangan Undang-Undang tentang Pengalihan Teknologi, tapi sekarang tidak diketahui bagaimana kelanjutannya.

Pengalaman negara-negara Amerika Latin dibidang alih tekonologi telah memperlihatkan akan arti pentingnya peraturan perundang-undangan tentang alih teknologi. Yang masih diperdebatkan adalah sifat dan lingkup pengaturannya, sehingga hukum alih teknologi baru ini dapat menampung perkembangan teknologi baru dan cara pengalihannya yang wajar dan luwes hingga tidak menimbulkan hambatanhambatan bagi kelancaran arus teknologi yang sangat diperlukan negara-negara berkembang. ${ }^{34}$

Sebagai perbadingan kiranya perlu kita ketahui, bahwa Brazil dan Mexico, semua kontrak lisensi teknologi wajib didaftarkan pada Instansi Pemerintah. Selain itu, di Brazil dalam Normative Act Nomor 15 Tahun 1975 yang merupakan pedoman tentang masalah alih teknologi, dengan tegas diadakan klasifikasi 5 macam kategori pokok perjanjian yang berkaitan dengan masalah teknologi masing-masing menurut obyekobyek yang diperjanjikan. ${ }^{35}$

1. Lisensi dan eksploitasi paten atau penemuan;

2. Lisensi untuk memakai merek dagang;

3. Perjanjian teknologi industri (Industrial technology agreement);

4. Perjanjian kerjasama teknik industri (technical industrial cooperation agreement); dan

5. Perjanjian kerjasama jasa-jasa teknik khusus (specialized services agreement).

Masing-masing kategori perjanjian tersebut di atas tunduk pada ketentuan hukum yang berbeda, baik mengenai prosedur eksaminasi untuk memperoleh pengesahan dari pemerintah, jumlah royalty dan cara pembayaran lainnya yang diperkenankan UU, maupun efektivitas berlakunya perjanjian bagi para pihak dan pihak ketiga.

Pola yang sama juga berlaku di Mexico yang diatur dalam Law Regulating the Transfer Of Technology and the Use and Exploitation of Patens and Trademarks dengan sedikit variasi serta satu penambahan, yaitu perjanjian Jasa-Jasa 
Administrasi dan Operasi (Services for the administration and operation).

\section{DAFTAR PUSTAKA}

\section{Literatur}

Dunning, Jhon $\mathrm{H}$, (ed), The Multinational Enterprise, George Allen \& Edwinn Ltd. London, 1971.

Frame, J. Davidson, Intemational Business and Global Technology, Lexington Books, Lexington, Massachusetts, 1984.

Habibie, B.J., IImu Pengetahuan, Teknologi dan Pembangunan Bangsa, Badan Pengkajian dan Penerapan Teknologi (BPPT), Jakarta, 1985.

Rajagukguk, Erman, Indonesianisasi Saham, Bina Aksara, Jakarta, 1985.

Robinson, Ricard D., The Intemational Transfer Of Technology, Theory, Issue, and Practise. Ballinger Pubtishing, Cambridge, 1988.

Voskuil, C.C.C., eds. al., Hague - Zagreb essay 6 on the Law of Intemational Trade : Crediet and Guarantee Financing Transfer of Technology, Martinus Nijhoff, Dordrecht, 1987.

Yelpaala, Kojo, et al. (eds) Licencing Agreements : Patents, Know How, Trade Secrets and Software, Kluwer, Deventer, 1988.

Tinjauan Praktek Bisnis Restriktif, Departemen Penerangan, Jakarta, 1992. (untuk kalangan sendiri).
Makalah dan Majalan Ilmiah.

B, Michael, "Legal Arrangement for the Commercial Acquistition of Technology," Makalah pada National Seminar Licencing and Technology Transfer Arrangement, yang diselenggarakan WIPO, di Jakarta, tanggal 7 - 8 Maret 1990.

Lumenta, J.B., "Beberapa Aspek Hukum Lisensi Paten dalam Praktek," makalah pada Program Pendidikan Khusus Konsultan Universitas Tarumanegara, Jakarta, 13 Mei - 19 Juni 1991.

, "Pengaturan Masalah Alih Teknologi Suatu Tinjauan Komperatif," Amroos Law Consultants, Jakarta, 1991.

Taylor, Roger. D., "Technology Transfer and Invesment The Transferror's Perspective, "Makalah pada National Seminar on Licencing and Technology Transfer Arrangement, yang diselenggarakan WIPO, di Jakarta, tanggal 7 - 8 Maret 1990.

Majalah Prisma, edisi : No. 4 Tahun XVI April 1987

\section{Dokumen}

Hasil Seminar Aspek-Aspek Hukum dari Pengalihan Teknologi, yang dipublikasikan BPHN - Bina Cipta, 1981.

North/South Technology, OECD, Paris, 1981.

WIPO Licencing Guide for Developing Countries, WIPO, Geneva, 1977.

UNCTC, Transnational Corporations and Technology Transfer: Effecs and Policy Issues, United Nations, New York, 1982.

UU No. 6 Tahun 1989

UU No. 19 Tahun 1992

Terjemahan Resmi Persetujuan Akhir putaran Uruguay.

*) Ridwan Khairandy, SH, M Hum, adalah alumni FH UII. Gelar, magister diraih dari Universitas Padjajaran Bandung. Kini sebagai dosen FH UII, serta menjabat Pembantu Dekan III. 